\title{
THE EFFECT OF LONG TERM STORAGE ON PHYSICAL AND CHEMICAL PROPERTIES OF POTATO
}

\author{
Erdogan OZTURK ${ }^{*}$, Taskin POLAT \\ Atatürk University, Faculty of Agriculture, Department of Field Crops, Erzurum, TURKEY \\ ${ }^{*}$ Corresponding author: erozturk@atauni.edu.tr
}

Received: 24.08 .2016

\begin{abstract}
Determination of physical and chemical properties of products such as potato in the long term storage and their variations is one of the significant specifications in terms of consumer preference and reaching high product quality. Therefore, it is a significant issue to know the changes that may occur on quality and physiological values of potato in the long term storage as much as its cultivation and breeding. With this research, the physical properties such as weight loss and the chemical properties such as specific gravity, dry matter, starch, protein contents and chips efficiencies were determined at the end of storage period of potato cultivars (Binella, Granola, Banba, Natascha, Toscana, Slaney and Marfona). The experiment was established as completely randomized designs with three replicates in 2013 and 2014 years . At the end of storage period, significant differences were determined among the potato cultivars according to the changes that occurred on physical and chemical properties of potato tubers. The weight loss was determined on all cultivars at the end of storage. The chemical properties of some potato cultivars increased while decreasing at some of them. The changes at the rates of $\mathbf{- 2 . 0 3 \%}$ in terms of weight, $\mathbf{0 . 0 6 \%}$ in terms of specific gravity, $-1.46 \%$ dry matter, $\mathbf{2 . 9 5 \%}$ starch, $\mathbf{7 . 8 5} \%$ protein and $\mathbf{- 5 . 4 3 \%}$ were determined in accordance with the general average of potato cultivars at the end of storage. Consequently, it was determined that there were increased and decreased on specific gravity, starch, protein, dry matter and chips efficiency among the chemical properties along with that these changed in accordance with the cultivars at the potatoes which were stored in the long term ( 24 weeks) controlled conditions. The results of studies presented that the physical and chemical changes occurred on the tubers in the long term storage depend on the potato cultivars.
\end{abstract}

Keywords: Chemical properties, cultivar, physical properties, potato, storage

\section{INTRODUCTION}

The potato that is a significant nutritional source in human nutrition is one of the most significant cultivated plants that may fulfill the growing hunger problem of our world. The potato of which production is made in 125 countries in the world and in the regions having $4000 \mathrm{~m}$ altitude above the sea level is accepted as the fourth product which is most produced in the world following wheat, rice and corn. The potato which contains protein of high biological value as well as that it has a significant starch content also includes group B vitamins, vitamin C and minerals such as potassium.

The potato has a wide consumption and use field is required to be short or long term stored within the periods when there is no potato production. The potato tubers are living creatures that make respiratory even after the harvest. Therefore they may substantially lose their weights and qualities by being subjected to matter loss during the respiratory. It leads to weight and nutritional losses along the storage period that the potato tubers have high moisture content and metabolic activity (Gottschalk and Ezhekiel, 2006). These losses are mostly resulted from respiratory, transpiration and sprout development (Burton et al., 1992). The sprout development increases weight loss, shrinkage and the toxic alkaloid accumulation and tuber texture, hardness and nutritive value had been decreasing (Sorce et al., 2005; Delaplace et al., 2008). In case the dehydration exceeds 5\% during long storage of potatoes, significant changes occur at their qualities due to excessive withering and mellowing (Smith 1952; Joiner and Mackey, 1962; Sparks, 1965; Burton, 1966; Schippers, 1971). Burton (1966) stated that a weight loss at $0.15 \%$ occurs within the timeframe of last a few months of long storage period. Schippers (1971) stated that the losses of tuber weights showed a linear increase as the storage period increases. The storage of potato tubers at low temperatures $\left(2-4{ }^{\circ} \mathrm{C}\right)$ indicates that offshoot development has been prevented for a long period and the sugar accumulation adversely affecting the chips quality has increased (Daniels-Lake and Prange, 2007; Kumar et al., 2007). It was determined that there was a significant decrease at starch content of potato which is one of quality criteria of potato with the long storage periods 
(Berghtaller and Putz, 1978). Depending on the different storage periods, it was determined that the tuber weight decrease at tubers of some potato cultivars chips efficiency and the oil ratio of chips increased and there was no any change on protein content (Kara, 1996). Kara (2004) stated that the weight losses of potato cultivars changed varying at $5.78-13.49 \%$, specific gravities at $0.85-0.82 \%$, dry matters at $-9.20-10.26 \%$ and starch content at $-14.40-15.68 \%$ at the end of storage period. It was also determined that the dry matter and the components forming the dry matter relatively increased during the storage (Sengül and Keleş, 2005). Golmohammadi and Afkari-Sayyah (2013) determined that significant changes occurred at physical properties of potato tubers which had been stored for a long period.

The physical and chemical properties that may occur during storage of potato also adversely affect the acceptability of potato by the consumer. The studies that aim to determine changes under the storage conditions are significant in terms of minimizing the adverse effect on the product quality. With this research, it was aimed to determine of the changes that occur on physical and chemical properties of tubers of potato cultivars (Binella, Granola, Banba, Natascha, Toscana, Slaney and Marfona) at the end of storage period.

\section{MATERIALS AND METHODS}

\section{Material Preparation}

In this research, Binella, Granola, Banba, Natascha, Toscana, Slaney and Marfona potato cultivars which are cultivated in Turkey were used. Binella is an early season cultivar and its efficiency high and consumed as table potato. Their tuber form is oval, the color of their skins is yellow and smooth, its flesh color is light yellow and pore size is outcrop. Granola is a mid-late season cultivar and its efficiency high and dry matter content is medium. The cultivar is very good market quality. Its tuber form is short and oval and its skin is very rough and yellow and it is very fleshy and it has very deep pores. Banba is a very late season cultivar and its efficiency is high and dry matter content is medium. Its tuber form is oval and tuber eye depth is superficial. The tuber skin color is yellow and tuber flesh color is light yellow so it is recommended as finger potato. Natascha is a mid-early season and productive cultivar. It is consumed as edible potato. Its tuber form is oval, tuber skin color is yellow and flesh color is dark yellow. The tubers are smooth shaped, shiny, attractive, very delicious and tradable and the number of the tuber is high. Marfona is a mid-early season, high productive and its dry matter content is low. The tuber forms are short oval, light yellow fleshy, its skin is smooth and it is very bulky and its market quality is very good and it is a cultivar preferred by the producers. Toscana is edible and it is within the mid season potato group. Its market quality is good, flesh color is yellow and tuber form is oval. Slaney is a very late season product and it is used as edible potato. The tuber form is very short, skin olor is yellow and flesh color is cream.
In the storage procedure, the tubers belonging to the potato cultivars (Binella, Granola, Banba, Natascha, Toscana, Slaney and Marfona) produced and harvested in 2013 and 2014 in Erzurum Ataturk University Faculty of Agriculture. Exactly $5 \mathrm{~kg}$ per each was taken from the potato tubers harvested as starting material and they were put into string bags and put into a store of which temperature varied at $4-6{ }^{0} \mathrm{C}$ and store humidity at 90 $98 \%$. Total storage period was 24 weeks. At the end of storage periods, 30 tubers were randomly selected from every cultivar and the physical and chemical properties of tubers were determined. The data obtained were analyzed with three replicates according to completely randomized designs over the combine average of years due to that there was no significance between the years. The data obtained from the research result were subjected to variance analysis with the help of SPSS software and the differences between the averages were determined with DUNCAN's multiple comparison test.

\section{Determination of Physical and Chemical Properties}

Below methods were used for analyses of tuber samples taken from potato cultivars.

1. Weight loss: $5 \mathrm{~kg}$ from each tuber of every cultivar was weighted and stored. These tubers stored were weighted again at the end of storage period and the difference was stated as weight in terms of \% compared to the first weighing.

2. Specific gravity change: By determining the specific gravity of tuber samples belonging to the relevant cultivars with the help of "Weighing in Air-Water" method before and after storage, the difference was proportioned to the values and specific gravity change was determined.

3. Dry matter change: The tuber samples belonging to the cultivars were first washed before and after the storage, then dried and after sliced, 100 gram sample was taken from each and dried at the laboratory environment and then kept for 24 hours in the drying chamber set up to $105{ }^{\circ} \mathrm{C}$, reweighted and dry matter rates were calculated by proportioning their fresh weights (Kaçar, 1972). The differences obtained at the end of storing were proportioned with the first weighing and the dry matter change was determined in term of $\%$.

4. Starch change: The starch contents of potato tuber samples belonging to cultivars were assigned before and after the storage by using "Ewers Method" (Anonymous, 1974). The differences obtained at the end of storing were proportioned with the first weighing and the starch change was determined in term of $\%$.

5. Crude protein change: First $\mathrm{N}$ contents of tuber samples grinded after the dry matter assignment were determined by using Kjeldahl method (Kadaster, 1960) and the values determined were multiplied with 6.25 coefficient and crude protein contents belonging to the potato tubers were determined before, along and after the storage (Augustin, 1975). Then, the differences obtained along and at the end of storage were proportioned with the 
first weighing and the starch change was determined in term of $\%$.

6. Chips efficiency change: After the potato tubers were washed and sliced with chips slicer (at the thickness of 1.0-1.5 mm), 100 gram per each was weighted, washed in cold water and dewatered between two towels. Then the slices at the weight of 100 gram were fried at $190{ }^{\circ} \mathrm{C}$ for 2 minutes and after cooling, they were weighted and their chips efficiency values belonging to the potato tubers were calculated before and after storage as percentage of fresh weight (Senol, 1973). Then, the differences obtained after the storage were proportioned to pre-storage values and the change relevant to the chips efficiency was determined in terms of $\%$.

\section{RESULTS AND DISCUSSION}

The starting values of tubers belonging to different potato cultivars that were determined immediately before the storage in terms of physical properties (weight loss) and chemical properties (specific gravity, dry matter, starch, protein and chips efficiency changes) are given in Table 1.

Table 1. The average starting values of tubers for different potato cultivars that were determined immediately before the storage in 2013 and 2014

\begin{tabular}{|c|c|c|c|c|c|c|c|}
\hline Treatments & & $\begin{array}{c}\text { Weight } \\
\text { (g) }\end{array}$ & $\begin{array}{c}\text { Specific } \\
\text { Gravity }(\%)\end{array}$ & $\begin{array}{c}\text { Dry Matter } \\
\text { Content }(\%)\end{array}$ & $\begin{array}{c}\text { Starch } \\
\text { Content } \\
(\%)\end{array}$ & $\begin{array}{c}\text { Protein } \\
\text { Content }(\%)\end{array}$ & $\begin{array}{c}\text { Chips } \\
\text { Efficiency } \\
(\%)\end{array}$ \\
\hline \multirow{8}{*}{$\begin{array}{c}\text { Cultivar } \\
\text { (V) }\end{array}$} & Marfona & 5000 & 1.078 & 20.57 & 13.60 & 8.43 & 31.58 \\
\hline & Toscana & 5000 & 1.066 & 18.41 & 10.94 & 8.78 & 30.12 \\
\hline & Binella & 5000 & 1.077 & 21.06 & 13.10 & 7.72 & 32.89 \\
\hline & Banba & 5000 & 1.069 & 19.74 & 11.59 & 8.18 & 31.91 \\
\hline & Slaney & 5000 & 1.069 & 18.09 & 11.60 & 8.33 & 31.44 \\
\hline & Granola & 5000 & 1.079 & 21.51 & 13.40 & 7.93 & 32.64 \\
\hline & Natascha & 5000 & 1.068 & 18.63 & 11.25 & 10.59 & 31.49 \\
\hline & Mean & 5000 & 1.072 & 19.72 & 12.21 & 8.57 & 31.72 \\
\hline
\end{tabular}

The assessments concerning to physical and chemical characteristics of potato cultivars are summarized in Table 2. Statistical differences $(\mathrm{p}<0.01)$ were determined compared to the starting values in terms of weight loss, specific gravity, dry matter, starch and protein contents of tubers among the potato cultivars except for chips efficiency. Increases and decreases that were not uniform were observed at physical and chemical properties of potato tubers along the storage period. When average of values determined at potato cultivars were taken into consideration, it was determined that there was a decrease at weight loss, dry matter and chips efficiency at the end of storage period while there was an increase at specific gravity, protein and starch amounts (Table 2).

Table 2. The physical and chemical properties of potato cultivars

\begin{tabular}{|c|c|c|c|c|c|c|c|c|}
\hline Treatments & & $d f$ & $\begin{array}{c}\text { Weight } \\
\text { Change } \\
(\%)\end{array}$ & $\begin{array}{c}\text { Specific } \\
\text { Gravity } \\
\text { Change }(\%)\end{array}$ & $\begin{array}{c}\text { Dry } \\
\text { Matter } \\
\text { Change } \\
(\%)\end{array}$ & $\begin{array}{c}\text { Starch } \\
\text { Change } \\
(\%)\end{array}$ & $\begin{array}{c}\text { Protein } \\
\text { Change } \\
(\%)\end{array}$ & $\begin{array}{c}\text { Change of } \\
\text { Chips } \\
\text { Efficiency }(\%)\end{array}$ \\
\hline \multirow{2}{*}{$\begin{array}{c}\text { Year } \\
(\mathbf{Y})\end{array}$} & 2014 & & -2.02 & 0.08 & -1.45 & 3.09 & 8.40 & -6.23 \\
\hline & 2015 & & -2.04 & 0.04 & -1.47 & 2.81 & 7.30 & -4.63 \\
\hline \multirow{8}{*}{$\begin{array}{l}\text { Cultivar } \\
\text { (C) }\end{array}$} & Marfona & & $-2.49 b c$ & $-0.55 c$ & $-4.32 b$ & $-8.47 \mathrm{~d}$ & $8.45 \mathrm{~b}$ & -4.04 \\
\hline & Toscana & & $-1.59 a$ & $0.28 \mathrm{~b}$ & $-3.19 b$ & $5.72 \mathrm{c}$ & $14.07 \mathrm{a}$ & -5.69 \\
\hline & Binella & & $-1.32 \mathrm{a}$ & $-0.93 c$ & $-2.43 b$ & $-8.47 \mathrm{~d}$ & $-10.41 \mathrm{~d}$ & -4.17 \\
\hline & Banba & & $-2.74 c$ & $1.05 \mathrm{a}$ & $7.92 \mathrm{a}$ & $20.62 \mathrm{a}$ & $16.80 \mathrm{a}$ & -3.85 \\
\hline & Slaney & & $-1.88 \mathrm{ab}$ & $0.79 \mathrm{a}$ & $8.38 \mathrm{a}$ & $14.15 \mathrm{~b}$ & $-2.42 c$ & -5.34 \\
\hline & Granola & & $-2.54 b c$ & $-0.56 c$ & $-9.96 b$ & $-7.44 d$ & $12.55 \mathrm{ab}$ & -8.40 \\
\hline & Natascha & & $-1.68 \mathrm{a}$ & $0.33 \mathrm{~b}$ & $-6.64 b$ & $4.54 \mathrm{c}$ & $15.93 \mathrm{a}$ & -6.55 \\
\hline & Mean & & -2.03 & 0.06 & -1.46 & 2.95 & 7.85 & -5.43 \\
\hline \multirow{3}{*}{$\begin{array}{c}\text { Analysis of } \\
\text { Variance }\end{array}$} & $\mathbf{Y}$ & 1 & ns & ns & ns & ns & ns & ns \\
\hline & $\mathbf{C}$ & 6 & $* *$ & $* *$ & $* *$ & $* *$ & $* *$ & ns \\
\hline & $\mathbf{Y} \times \mathbf{C}$ & 6 & ns & ns & ns & ns & ns & ns \\
\hline
\end{tabular}

**Significant on the level of $1 \%$; ${ }^{\text {ns }}$ non-significant 


\section{Weight Change}

The weight loss that occurred at the potato cultivars at the end of storage period was averagely $-2.03 \%$. The weight loss determined at potato cultivars varied between $-2.74 \%$ and $-1.32 \%$. Maximum weight loss was determined at Banba cultivar $(-2.74 \%)$, Granola $(-2.54 \%)$, Marfona (-2.49\%), Slaney $(-1.88 \%)$, Toscana $(-1.59 \%)$ and Natascha $(-1.68 \%)$ cultivars followed it. Minimum weight loss was determined at Binella $(-1.32 \%)$ among the potato cultivars (Table 2, Figure 1). The difference between the losses of weight may be resulted from that the breathing and transpiration cases are different among the cultivars. But the weight losses occurred at the potato cultivars stayed low due to that the storage humidity was high and temperature was appropriate. It is known that continuance of breathing activities after the harvest leads to dehydration and therefore weight loss. It is known that there may be storage losses at the rate of 7-9\% even under the appropriate storage conditions as the potato is a living creature that makes aspiration (Er and Uranbey, 1999). It was stated by various researchers that he weight losses occurred along the storage vary depending on extension of storage period and relative humidity ratio (Schippers, 1971; Sparks, 1973; Karadoğan, 1994; Kara, 1999). In the similar way, it is sated that the weight losses at the potato tubers increase along with the extension of storage period (Kubicki and Zagroska, 1980; Kara, 2000; Kara 2004).

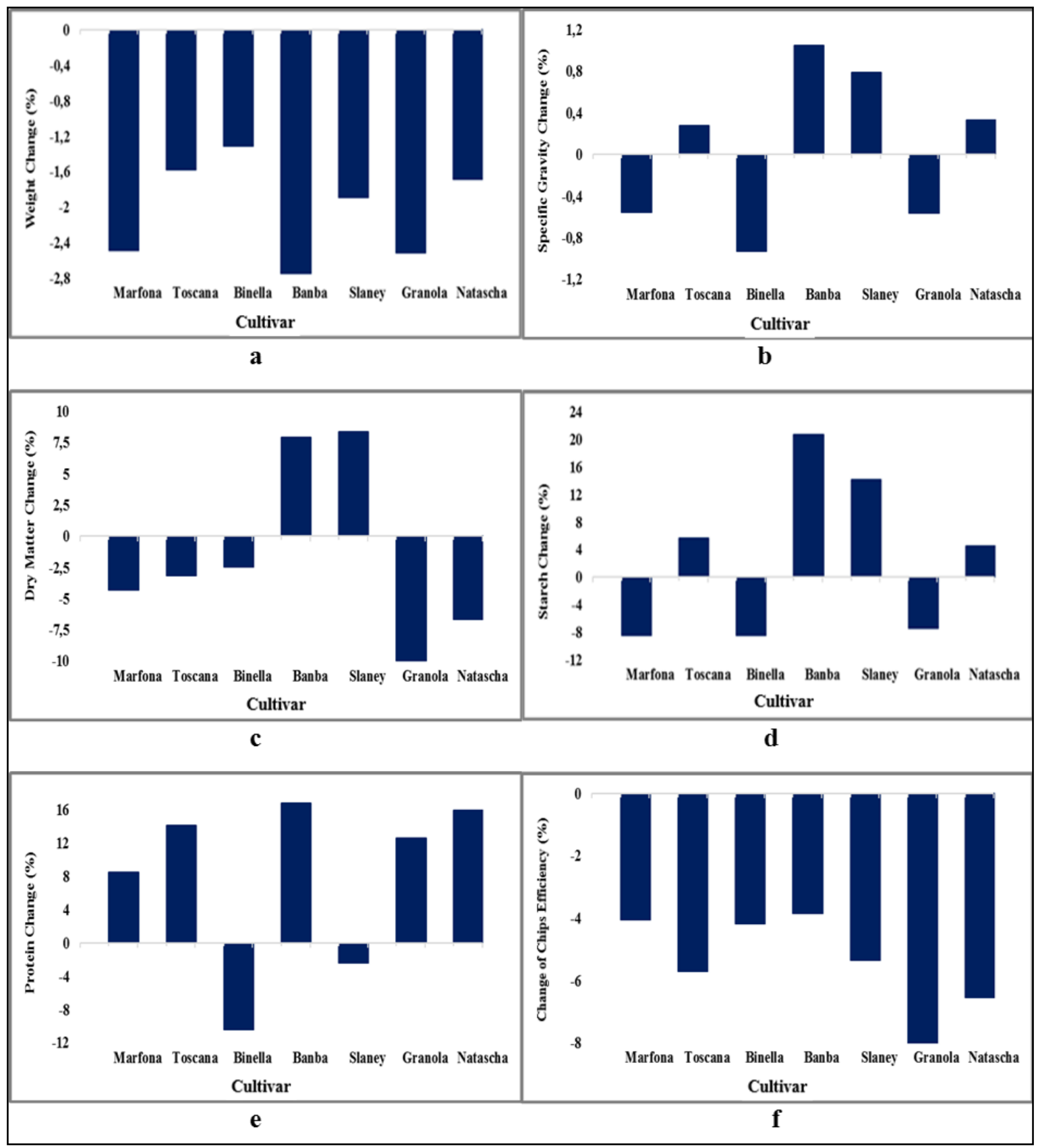

Figure 1. Variation of the (a) weight change, (b) specific gravity change, (c) dry matter change, (d) starch change, (e) protein change and (f) change of chips efficiency during the storage period of poatato cultivars. 


\section{Specific Gravity Change}

Although there is an increase in terms of specific gravity at some cultivars at the end of storage, decrease occurred at some cultivars and in this case, the specific gravity change was not uniform. While there was a decrease at specific gravity values of Marfona (-0.55\%), Binella $(-0.93 \%)$ and Granola $(-0.56 \%)$ tubers compared to the starting values, an increase was observed at Toscana $(0.28 \%)$, Banba $(1.05 \%)$, Slaney $(0.79 \%)$ and Natascha $(0.33 \%)$ cultivars which were other potato cultivars. While maximum decrease in terms of specific gravity was at Marfona at the rate of $-0.55 \%$, maximum increase was at Banba at the rate of $1.05 \%$ (Table 2, Figure 1). Hence, Stevenson et al. (1964) stated that the specific gravity is genetic but the factors such as temperature, relative humidity, storage period, etc. are effective on the specific gravity. In other studies concerning to this subject, it was determined that the specific gravity varied according to the cultivars (Kara, 2000; Kara, 2004). Kara (2004) stated that the specific gravity changes carried between $-0.85 \%$ and $0.82 \%$ and these results showed similarity with the research results.

\section{Dry Matter Change}

It was stated that the change at dry matter rate of potato cultivars were not stable along the storage and there was a change at the rate of $0.06 \%$ averagely. The change at the dry matter rates was in the direction of decrease for Marfona (-4.32\%), Toscana (-3.19\%), Binella $(-2.43 \%)$, Granola $(-9.96 \%)$ and Natascha $(-6.64 \%)$ and in the direction of increase for Banba $(4.24 \%)$ and Slaney $(5.72 \%)$ cultivars (Table 2 , Figure 1$)$. It is stated that the cultivar of changes occurred at the dry matter depends on storage temperature and relative humidity (Lisinska and Leszcynski, 1989). It has been also stated in the similar studies that the changes at the dry matter rate determined on the potato cultivars at the end of storage were not uniform (Toma et al., 1979; Kara, 1996; Kara, 2000). It was stated that the change of dry matter after the storage varied at the rates of $-9,20 \%-10,26 \%$ (Kara, 2004). The values obtained from the experiment showed similarity with these results. In similar studies, it was determined that the dry matter and components forming the dry matter relatively increased along the storage period (Dede et al., 1999; Sengul and Keles, 2005).

\section{Starch Change}

Differences were observed among the potato cultivars in terms of increase and decrease of starch content along the storage period. An increase at the rate of $2.95 \%$ was determined on the starch change according to average of cultivars at the end of storage. The changes at starch content of cultivars varied between $-8.47 \%$ and $20.62 \%$. While the highest starch change belonging to the cultivars was at Banba cultivar with $20.62 \%$ increase, Slaney followed by $14.15 \%$ change. In terms of decrease, the highest starch content change was at Marfona and Binella cultivars with $-8.47 \%$ (Table 2, Figure 1). The change on the starch content is correlated with the specific gravity change. High starch content is correlated with specific gravity and there is a direct proportion with two key aspects (Senol, 1970). Thus, the starch content change of cultivars was similar as parallel to specific gravity change. The starch content of cultivars that had specific gravity changes showed a change in the direction of decrease or increase. In the similar studies (Senol, 1971; Lisinska and Leszczynski, 1989; Kara, 1996; Altun, 1996; Kaya, 1999; Kara, 2000; Kara, 2004), it was put forth that different values were obtained among the cultivars in terms of starch content. At the end of storage, it was also determined by Dede et al. (1999), Kaya (1999) and Kara (2000) that there may be increases on starch content.

\section{Protein Change}

At the end of storage period, an increase at the rate of approximately $7.85 \%$ was determined in terms of protein content. The protein content change obtained from the potato cultivars showed an increase except for two cultivars (Binella and Slaney). Decreases at the rate of $10.41 \%$ and $-2.42 \%$, respectively were determined on the protein contents of these cultivars. While Banba (16.80\%) ranked first among the cultivars, Natascha (15.93\%), Toscana (14.07\%), Granola (12.55\%) and Marfona $(8.45 \%)$, respectively followed it (Table 2 , Figure 1$)$. The genetic structure of cultivars may have effect on these differences occurred in terms of the change at the protein content. In the similar studies, it was determined that the storage period leaded to differences on the protein content among the potato cultivars (Senol, 1971; Ertan, 1980; Lisinska and Leszczynski, 1989; Kara, 1996; Altun, 1996; Kaya, 1999; Kara, 2000; Kara, 2004).

\section{Change of chips efficiency}

Along the storage period in terms of chips efficiency, a decrease observed on chips efficiency at all potato cultivars and their values varied between $-8.40 \%$ and $3.85 \%$. While Granola chips efficiency is the cultivar that most decreased with $-8.40 \%$, Natascha (-6.55\%) and Toscana $(-5.69 \%)$ followed this. The changes of chips efficiencies of Marfona, Slaney, Binella and Banba cultivars occurred as $-4.04,-5.34,-4.14$ and $-3.85 \%$, respectively (Table 2, Figure 1).

\section{CONCLUSIONS}

It is seen that long term storage leads to physical and chemical changes on the potato tubers. According to average of values obtained from the tubers belonging to potato cultivars stored, a decrease on weight, dry matter and chips efficiencies and an increase on specific gravity, starch and protein contents were observed on the tubers. At the end of storage period, Banba and Slaney yielded better results in terms of the changes of specific gravity, starch, protein, dry matter and chips efficiency among the chemical properties and Binella and Toscana yielded better results in terms of gravity changes among physical properties compared to the other cultivars. At the end of storage periods, it was determined that the potato cultivars show a set of differences depending on their cultivar properties. The results of study submitted verified that the 
physical and chemical changes occurred at tubers in the long storage depend on potato cultivars.

\section{LITERATURE CITED}

Altun, M. 1996. The effect of storage temperature on starch and C vitamin levels of potato. Department of Chemistry, M.Sc.. Istanbul University. Graduate School of Natural and Applied Sciences, Master's Thesis.

Anonymous. 1974. Analitical Methods for Potato Research. No:A-6, The Inst. Res. On Storage and Process. Agrich Pred.

Augustin, J. 1975. Variations in the nutritional composition of fresh potatoes. Journal of food Science. 40, p: 1295-1299.

Burton, W.G. 1966. The Patato A Survey of Its History and of Factors İnfluencing Its Yield. Nutritive Value. Quality and Storage. H. Veen-man and Zonen N.V., Wageningen. Holland. $382 \mathrm{~s}$.

Burton, W.G., Es.A. Van, K.J. Harmants, 1992. The physics and physiology of storage. In P. M. Harris (Ed.). The potato crop. London, Champman and Hall.

Bergthaller, W. and B. Putz. 1978. LandwirtszchaftlicheForschung. Publ. Sonderheft 34-1, 134-143.

Daniels-Lake, B.J. and R.K. Prange. 2007. The canon of potato science, 41. Sprouting. Potato Research. 50: 379-382.

Dede, Ö., E. Günel, B. Yıldırım, B. Arslan and N. Okut. 1999. Effect of different forms and doses of nitrogen fertilizer on storage loss in potato. II. National Potato Congress, 28-30 June 1999. page 107-113, Erzurum.

Delaplace, P., Y. Brostaux, M.L. Fauconnier and P. Jardin. 2008. Potato (Solanum tuberosum L.) tuber physiological age index is a valid reference frame in postharvest ageing studies. Postharvest Biol Technol 50:103-106.

Er, C. and S. Uranbey. 1999. Starch and Sugar Crops. Ankara University, Faculty of Agriculture. Publication No: 1504 Textbook: 458, 334s, Ankara.

Ertan, U. 1980. Investigations on after yield physiology of important potato varieties produced in Adapazarı and around (PhD Thesis). Çukurova University, Faculty of Agriculture, Adana.

Golmohammadi, A. and A.H., Afkari-Sayyah. 2013. Long-Term Storage Effects on the Physical Properties of the Potato. International Journal of Food Properties. 16:104-113.

Gottschalk, K. and R. Ezhekiel. 2006. Storage. In "Handbook of Potato Production, Improvement, and Postharvest Management" Pp. 489-522, Food Products Press, New York London, Oxford.

Jonier, S. and A. Mackey. 1962. Weight Loss, Specific Gravity and Mealiness During Storage of Russert Burbank Potatoes. Am. Potato J. 39: 320-325.

Kacar, B. 1972. Chemical Analysis of Plant and Soil II. Plant Analysis. Ankara University, Faculty of Agriculture, Publications: 453, Ankara University, Faculty of Agriculture, Publications: 960. Ankara.

Kadaster, E. 1960. Agricultural Chemistry Exercise. First Book; Feed Analysis (2nd Edition). Ankara University, Faculty of Agriculture, Publication No: 113 Textbook No. 40 University of Ankara. Printing House.

Kara, K.1996. A research on some characteristics of potatoes varieties stored at different times. G1da. 21 (3): 215-225.

Kara, K. 1999. Effects of Haulm Killing and Pre-Sprouting on Yield and Yield Components of Potato (Solanum tubeosum
L.). II. National Potato Congress. 28-30 June 1990 p.298318.

Kara, K. 2000. The Effects of Storage Periods on Some Quality Features of Various-Sized Potato Varieties. Türk J Agric For. 24 (2000): 561-569.

Kara, K. 2004. Investigation of quality and physiological characteristics of some potato varieties after storage. Food. 29 (1) : 63-71.

Kara, K. 2011. Starch-Sugar Plant Cultivation and Breeding. Atatürk University Faculty of Agriculture. Course Publication No. 241.

Karadoğan, T. 1994. Effects of quality of potato of different fertilizer application at during Storage. I. Field Crops Congress, Volume 1: Agromonik Proceedings, pp: 180-184, Izmir.

Kaya, C. 1999. Storage on Controlled and Uncontrolled Environments of potato. Ataturk University, Graduate School of Natural and Applied Sciences, Department of Food Enginering, Master's Thesis.

Kubicki, K. and K. Zagorska. 1980. Causes of storage losses in potatoes. International- Zeitschrift-der-Landwirtscharft. No.6, 577-580.

Kumar, S., H.D. Khade, V.S. Dhokane, A.G. Behere and A. Sharma. 2007. Irradiation in Combination with Higher Storage Temperature Maintains Chip- Making Quality of Potato. Food Sci. J. 72: 402.

Lisinski, G. and W. Leszczynski. 1989. Potato tubers as a row material for processing and nutrition. In 'Potato Science and Technology' Edited by G. Lisinski and W. Leszczynski. Deparment of Storage and Food Tecnology. Agricultural Academy, Wroclaw, Poland.

Schippers, P.A. 1971. The Relation Between Storage Conditions and Changes in Weight and Specific Gravity of Potatoes. American Potato Journal. 48: 313-319.

Smith, W.L. 1952. Effect of Storage Temperature, Injury and Exposure on Weight Loss Surface Discoloration on New Potatoes. American Potato Journal. 29: 55-61.

Sorce, C., R. Lorenzi, B. Parisi and P. Ranalli. 2005. Physiological mechanisms involved in potato (Solanum tuberosum) tuber dormancy and the control of sprouting by chemical suppressants. Acta Horticulturae. 177-185.

Sparks, W.C. 1965. Effect of Storage Temperature on Storage Losses of Russert Burbank Poatatoes. American Potato Journal. 42: 241-246.

Sparks, W.C. 1973. Influence of Ventilation and Humiditiy During Storage on Weight and Quality Changes of Russet Burbank Potatoes. Potato Research. 16: 213.

Senol, S. 1971. Investigations on some important local and foreign potato varieties in Erzurum conditions. Atatürk University, Publications No.83, Faculty of Agriculture. Publication No.30, Research Series 10, Erzurum.

Senol, S. 1973. The effect of temperature, duration, the tuber specific gravity and cultivar property on sugar, dry matter and chips quality of tuber. Atatürk University, Publication No. 159. Faculty of Agriculture Publication No. 76.

Sengül, M. and F. Keles. 2005. The effects of storage conditions on physical and chemical properties of potato. Food. 30 (2): $103-103$

Toma, R.B., J. Augustin, R.N. Smith, R.H. True and J.M. Hopan. 1979. Proximate Composition of Freshly Harvested and Stored Potatoes (Solanum tuberosum L.) Journal of Food Science. 43:1702- 1704. 